\title{
PELATIHAN PENGELOLAAN MASJID MUHAMMADIYAH DI BANGUNTAPAN BANTUL
}

\author{
Oleh: \\ Waharjani, Miftah Khilmi Hidayatullah \\ E-mail: waharjani_fai@yahoo.com
}

\begin{abstract}
Ringkasan
Menurut data yang dikumpulkan Dewan Masjid Indonesia, di Daerah Istimewa Yogyakarta itu ada 7.331 masjid. Dari jumlah tersebut, masjid yang dikatakan makmur karena dikelola dengan baik, tidak lebih dari 50 masjid. Oleh karena itu tujuan pengabdian ini adalah pertama, menyusun buku Panduan Pengelolaan Masjid Muhammadiyah; kedua, melatihkan Panduan Masjid Muhammadiyah pada masjid Muhammadiyah di PCM Banguntapan Bantul pada 5 Pebruari 2017. Kegiatan pertama, dimulai dengan mengumpulkan literatur sebagai bahan dasar, kemudian proses penyusunan dan editing serta penggandaan pada 2 Nopember 2016 - 10 Januari 2017 sebagai materi induk pelatihan pengelolaan masjid. Kegiatan kedua sosialisasi dengan cara melatihkan panduan tersebut pada takmir-takmir masjid di PCM Banguntapan Bantul. Sekalipun kegiatan pengabdian pada masyarakat dalam bentuk pelatihan ini lancar, namun di antara kendala yang dirasakan pengabdi saat pelaksanaan pelatihan adalah kesibukan para pengurus takmir yang diundang, sehingga yang hadir tidak maksimal ( dari 30 orang utusan yang hadir 18 orang utusan).
\end{abstract}

Kata kunci: Masjid, Pengelolaan, Makmur, Muhammadiyah.

\begin{abstract}
According to data collected by the Indonesian Mosque Council, in the Special Region of Yogyakarta there are 7,331 mosques. Of these, the mosque is said to prosper because it is well managed, not more than 50 mosques. Therefore the purpose of this service is first, to compile Muhammadiyah Mosque Management Guide book; second, trained the Muhammadiyah Mosque Guide at the Muhammadiyah Mosque in PCM Banguntapan Bantul on February 5, 2017. The first activity, starting with collecting literature as a base material, then the process of drafting and editing and doubling on November 2, 2016 - January 10, 2017 as the main material of mosque management training. The second activity of socialization by way of tracing the guidance to takmir-takmir mosque in PCM Banguntapan Bantul. Although the community service in the form of training is smooth, but among the obstacles felt by the devotees during the training are the takmir officials who are invited, so that the attendees are not maximal (of the 30 delegates present in 18 delegates).
\end{abstract}

Keywords: Mosque, Management, Makmur, Muhammadiyah

\section{A. PENDAHULUAN}

Al-Qur-an telah menjelaskan tentang fungsi masjid dan urgensinya sebagaimana dalam firman Allah, "Bertasbihlah kepada Allah di masjid-masjid yang telah diperintahkan untuk dimuliakan dan disebut nama-Nya di dalamnya, pada waktu pagi dan waktu petang, laki-laki yang tidak dilalaikan oleh perniagaan dan tidak (pula) oleh jual beli dari mengingat Allah, dan (dari) mendirikan sembahyang, dan (dari) membayarkan zakat. Mereka takut kepada suatu hari yang (di hari itu) hati dan pengliahatan menjadi goncang”. (Qs.An-Nuur (24):36-37) 
Dari ayat diatas dapat dipahami bahwa Allah telah menetapkan tentang beberapa hak masjid, yaitu ia berhak untuk dimulilakan, diagungkan dan dihormati kesuciannya karena ia merupakan rumah Allah yang digunakan untuk beribadah oleh orang-orang yang shalat.

Sebagaimana disebutkaan di dalam Sabda Rasulullah di sebuah hadits Qudsi yang artinya:

"Sesungguhnya rumah-ku (Allah) di muka bumi adalah masjid-masjid. Maka beruntunglah siapa saja yang membersihkan diri (sejak) di rumahnya kemudian mengunjungi-Ku”.

Keagungan masjid adalah ia mampu melimpahkan berbagai kebaikan kepada orang yang senantiasa mengunjunginya, juga orang yang selalu mempersiapkan masjid dalam rangka menyambut kedatangan jama' ah untuk shalat dan bribadah di dalamnya. Sementara itu, asas dan fondasi bangunan masjid adalah kualiatas taqwa yang dikucurkan kepada umat Islam, karena keagungan dan ketinggian Islam juga karena kebesaran dan kehormatannya.

Masjid hanya digunakan untuk mengingat nama Allah. Sementara mengingat Allah itu mencakup beberapa bentuk yang sangat luas; antara lain shalat, adzan, membaca $\mathrm{Al}$ Qur'an dan mengajarkanya, mengajarkan beberapa cabang ilmu yang lain dan menyelenggarakan pendidikan di dalamnya.

Sementara kaum musyirikin mengingat nama tuhan-tuhan mereka di dalam rumahrumahnya yang beraneka ragam bentuk bangunannya, yang karenanya menghabiskan harta kekayaan dan kebaikan-kebaikan.

Memuji kepada Allah di dalam masjid pada waktu pagi dan petang maksudnya adalah melaksanakan shalat di dalamnya, sebagaimana dikatakan para musafir bahwa kata al-ghudduw manunjukkan makna shalat subuh. Sementatra kata al-ashal mununjukkan makna shalat zhuhur, ashar, maghrib dan isya'.

Ibnu Abbas berkata, "Setiap tasbih (memuji Allah) di dalamnya Al Qur'an menunjukan makna kepada shalat. Sementara masjid dipersiapkan untuk melaksanakan shalat yang jauh dari hiruk pikuk kesibukan duniawi; jauh dari keramaian pasar dan kesibukan perdagangan; dan jauh dari memikirkan pintu-pintu rezeki. Kondisi seperti itu menjadikan masjid tetap berada dalam keagungan dan kesuciannya yang layak untuk dijadikan sebagai tempat melaksanakan shalat yang penuh kekhusu'an dan ketundukan kepada Allah. Saat itu pikirannya tidak membayangkan kesibukan pasar, perdagangan dan perbuatan-perbuatan kotor. Orang-orang mukmin yang sungguh-sungguh keimanannya, kehidupan dunianya tidak akan memalingkan dari melaksanakan shalat ketika muadzin mengumandangkan adzan; tidak memalingkannya dari melaksanakan shalat ketika waktunya telah tiba; juga tidak memalingkannya dari taat kepada Allah yang dengan ketaatan itu jiwanya menjadi suci dan selamat dari fitnah."

Sebuah hadits dari Anas menuturkan bahwa Nabi Muhammad SAW bersabda,"Masjid itu hanya untuk mengingat Allah Azza wa Jalla, melaksanakan shalat dan membaca Al-Qur'an'.

Imam Ahmad berkata.'Tidaklah aku melilhat seseorang masuk masjid kecuali mewajibkan atas dirinya sendiri untuk mengingat dan memuji Allah, karena masjid dibangun untuk itu dan untuk shalat". 
Diterbitkan oleh Lembaga Pengabdian kepada Masyarakat

Universitas Ahmad Dahlan Yogyakarta

Dzikir dan tasbih menurut sebagaian ulama adalah membebaskan dan mengosongkan diri dari kelalaian dan kealpaan dengan cara melanggengkan kehadiran hati bersama Allah. Sementara masjid dibangun untuk melaksanakan i'tikaf di dalamnya dan berdiam diri di dalam masjid yang bertujuan untuk beribadah dengan cara tertentu dan disertai dengan niat yang tulus.

Allah Swt. bserfirman "Bersihkanlah rumah-Ku orang-orang yang thawaf, uang i'tikaf, yang ruku' dan yang sujud".(QS.Al-Baqarah (2):125) Allah juga berfirman, "Dan Masjidil Haram yang telah Kami jadikan untuk semua manusia yang bermukin (i'tikaf) di situ maupun di padang pasir". (QS.Al Hajj (22):25). Allah SWT. berfirman pula," Janganlah kamu campuri mereka itu, sedangkan kamu beri'tikaf di dalam masjid" (QS.Al Baqarah(2):187).

Disamping fungsi sebagai tempat mengingat Allah, masjid juga difungsikan sebagai tempat untuk mengatur dan mengelola kehidupan duniawi umat manusia dengan segala bentuk kebutuhan dan kepentingannya. Dengan demikian, masjid memiliki fungsi yang bersifat vertikal dan horizontal. Adapun fungsi horizontal masjid adalah sebagaimana yang akan dipaparkan di bawah ini.

\section{Tujuan Kegiatan Pengabdian}

Adapun tujuan pengabdian ini adalah sebagai berikut:

a. Menyusun buku Panduan pengelolaan Masjid Muhammadiyah.

b. Melatihkan Panduan Masjid Muhammadiyah pada takmir-takmir masjid di wilayah PCM Banguntapan Bantul pada 5 Pebruari 2017.

\section{Manfaat Pengabdian Dan Luaran}

Adapun pelaksanaan pengabdian ini adalah: 1. Tersusunnya panduan pengelolaan masjid Muhammadiyah; 2. Tersosialisasikannya panduan pengelolaan masjid Muhammadiyah pada masjid Muhammadiyah dalam bentuk pelatihan penggunaan panduan untuk memakmurkan masjid yang dikelola moleh para utusan takmir-takmir masjid se-wilayah PCM Banguntapan Bantul.

Luaran PPM: Buku Panduan Pengelolaan Masjid Muhammadiyah

\section{Profil Desa Banguntapan Bantul}

Banguntapan adalah salah satu kecamatan di Kabupaten Bantul yang berhimpitan dengan kota Yogyakarta.Penduduknya pada kampung tertentu sudah sama dengan suasana kampung yang ada di kota Yogyakarta, misalnya di dusun Babatan yang berhimpitan dengan kecamatan Umbulharjo. Akan tyetapi berbeda dengan dusun yang lain masih terasa suasana desanya. Penduduknya dalam memenuhi kebutuhan hidup sehari-hari ada yang di toko-toko modern yang tersebar hampir merata, banyak juga yang berbelanja di pasar-pasar di wilayah kota. Seperti di pasar Kotagede, pasar sentra buah dan sayur Giwangan, pasar Sentul, bahkan ke pasar Beringharjo.Dari segi penduduk Banguntapan utara tetap mayoritas Jawa, akan tetapi pendatang juga cukup banyak baik dari pulau Jawa maupun dari luar Pulau Jawa. Adapun penduduk yang mayoritas beragama Islam, mereka di dalam beribadah di Masjid-masjid. Yang beragama Budha beribadahnya di Pura Sorowajan, sedang yang Kristen dan Katolik di Gereja yang tersebar di wilayah Banguntapan utara. 
Kaitan profil ini dengan kegiatan pengabdian ini adalah Masjid. Masjid di wilayah Banguntapan utara ini diantaranya ada 30 Masjid, selebihnya belum terdata.Masjid-masjid tersebut kelihatan semarak terlihat pada hari Jum'at dan pada bulan Ramadhan, selain itu semaraknya sesuai kualitas keislaman warga sekitar masjid dan keaktifan pengurus takmirnya. Masjid yang dapat dikatakan terkelola dengan baik adalah ke- 30 masjid tersebut, sekalipun belum merata kualitas peneglolaan dan tingkat keislaman jamaahnya. Ormas Islam yang paling banyak berkiprah adalah Muhammadiyah dan Nahdhatul Ulama'. Mubaligh yang diterjunkan untuk membina umat cukup banyak, tidak kurang dsari 70 orang yang tiap hari jum'at bertugas sebagai khotib jum'at dan sebagai pengisi ceramah pada bulan Ramadhan, sekalipun bergitu masih dibantu dengan Mubaligh yang berasal dari kota Yogyakarta.

\section{B. PELAKSANAAN KEGIATAN}

Kegiatan pengabdian ini mencakup dua kegiatan pokok, yaitu:

a. Penyusunan Panduan Pengelolaan Masjid Muhammadiyah.

b. Sosialisasi panduan pengelolaan Msjid Muhammadiyah.

Kegiatan pertama, dimulai dengan mengumpulkan literatur sebagai bahan dasar, kemudian proses penyusunan, editing serta penggandaan pada 2 Nopember 2016 - 10 Januari 2017. Kegiatan kedua sosialisasi, yaitu difokuskan pada takmir-takmir masjid sewilayah PCM Banguntapan Bantul.

Tabel.1 Waktu, Materi, dan Nara Sumber.

\begin{tabular}{|c|c|c|c|}
\hline No & Waktu & Materi & Frekuensi \\
\hline 1 & $\begin{array}{c}2 \\
\text { Nop. } 2016 \\
\text { s.d. } 10 \\
\text { Jan. } 2017\end{array}$ & $\begin{array}{c}\text { Penyusunan, editing, penggandaan } \\
\text { Panduan Pengelolaan Masjid } \\
\text { Oleh: Dr. Waharjani, M. Ag. }\end{array}$ & 1 kali \\
\hline 2 & $\begin{array}{c}\text { P Peb. } \\
2017 \\
08.00- \\
11.30\end{array}$ & $\begin{array}{l}\text { Sejarah dan fungsi Masjid pada } \\
\text { Zaman Rasulullah Saw. } \\
\text { Oleh: Miftah. Hilmi Hidayatullah, } \\
\text { Lc, M. Hum. }\end{array}$ & 1 kali \\
\hline 3 & $12.30-$ & Menejemen Pengelolaan Masjid & 1 kali \\
\hline & 14.30 & Oleh : Dr. Waharjani, M. Ag & \\
\hline 4 & $\begin{array}{c}14.30- \\
16.00\end{array}$ & $\begin{array}{l}\text { Diskusi : Problema Pengelolaan } \\
\text { Masjid dan penyelesaiannya } \\
\text { Oleh : Peserta dan Dr. Waharjani, } \\
\text { M. Ag dan Miftah Khilmi } \\
\text { Hidayatullah, Lc., M. Hum }\end{array}$ & 1 kali \\
\hline
\end{tabular}


Diterbitkan oleh Lembaga Pengabdian kepada Masyarakat

Universitas Ahmad Dahlan Yogyakarta

\section{Metode Yang Diterapkan}

Bentuk pengabdian ini adalah pelatihan pada takmir-takmir masjid Muhammadiyah se-wilayah PCM Banguntapan Bantul.

\section{Kendala Pelaksanaan}

Diantara kendala yang dirasakan pengabdi adalah kesibukan para pengurus takmir yang diundang, sehingga yang hadir tidak maksimal, dari 30 orang pengurus takmir masjid, yang hadir 18 orang.

\section{KESIMPULAN DAN SARAN}

Dari uraian diatas, dapatlah penulis memberikan kesimpulan sebagai berikut:

1. Dua kegiatan dapat berjalan sesuai rencana.

2. Kegiatan sosialisasi peserta kurang maksimal.

Saran: kegiatan kedua, dapat dilanjutkan sehingga tujuan dapat terwujud dan menjangkau lebih banyak pengurus masjid Muhammadiyah. Sedang buku panduan perlu penyempurnaan yang berkaitan masukan-masukan yang disampaikan para peserta pelatihan.

\section{DAFTAR PUSTAKA}

Al-Arifin, Widjan. Pembinaan masjid Muhammadiyah. MTDK PWM DIY. 2005. Asadullah Al Faruq, Panduan Lengkap Mengelola \& Memakmurkan Masjid. Solo: Pustaka Arafah, 2010

Khairuddin Wanili, Ensiklopedi Masjid. Jakarta: Darus Sunnah Press, 2008
MTDK PP Muhammadiyah. Dakwah Islam Kontemporer Tantangan dan Harapan. Yogyakarta: MTDK PP Muhamadiyah. Cetakan I. 2004.

Muhammad Jamaluddin Al Qasimi, Bid ah-bid ah dalam Masjid. Jogyakarta: Maktabah Al-Aiisar, t.th.

Pimpinan Pusat Muhammadiyah, Berita resmi Muhammadiyah Tanfidz Keputusan Muktamar Muhammadiyah Satu Abad. PP Muhammadiyah, Himpunan Putusan Tarjih. PP Muhammadiyah, t.th.

Said Tahulele, callpaper: Masjid, Rekonstruksi Wawasan Kemanusiaan, dan Pemberdayaan Umat, Masjid Syuhada, Yogyakarta, 2002.

Sarwono, Ahmad, Masjid Jantung Masyarakat, Izzan Pustaka, Yogyakarta, cetakan I, 2003

Sufaat Mansur, Manajemen Masjid. Manajemen sederhana untuk Masjid di desa atau kampung. Yogyakarta; Ak Group, 2011.

Supardi dan Teuku Amirudin. Manajemen Masjid dan Pembangunan Masyarakat Optimalisasi dan Fungsi Masjid. UII Press Yogyakarta. 2001.

TIM Penyusun Kanwil Departemen Agama. DIY, Pedoman Pemberdayaan Masjid, Proyek Peningkatan Pemahaman Pengalaman Agama dan Kerukunan Hidup Umat Beragama DIY, Tahun 2003. 
